BIOFARM

Jurnal Ilmiah Pertanian

ISSN Print: 0216-5430; ISSN Online: 2301-6442

Vol. 14, No. 1, April 2018

\title{
Potensi Tepung Pakan Alternatif dari Maggot dan Azolla (Malla) sebagai Bahan Baku Pakan Ternak dengan Kandungan Protein Tinggi
}

\author{
Alternative Feed Flour Potential from Maggot and Azolla (Malla) as Animal \\ Feed Raw Materials with High Protein Content
}

\author{
Sajuri \\ Program Studi Agroteknologi, Fakultas Pertanian, Universitas Pekalongan
}

\begin{abstract}
ABSTRAK
Ketersediaan pakan merupakan faktor utama dari suksesnya usaha peternakan, baik berupa peternakan ungas, pemamah biak, maupun ikan. Pakan dapat dibedakan menjadi pakan alami dan pakan buatan. Bahan baku utama penunjang protein yang sering digunakan adalah limbah ikan, namun ketersediaannya fluktuatif. Potensi bahan baku alternatif dengan kandungan protein tinggi diantaranya adalah maggot dari lalat Hetermia illucens yang memiliki kandungan protein hewani dan tanaman azolla yang memiliki kandungan protein nabati. Penulisan ini menggunakan metode diskriptif yaitu penulisan yang mengacu pada pemecahan masalah yang aktual, pengumpulan data, disusun, dijelaskan dan di analisis. Pembahasan masalah dengan menggunakan studi pustaka dan hasil uji laboratorium sebagai sumber informasi. Hasil dari kegiatan ini adalah terciptanya produk tepung pakan malla yang memiliki tiga produk turunan yang dibuat menjadi tiga grade. Kandungan proksimat yang dimiliki tepung pakan Malla grade 1 antara lain protein $33.70 \%$, lemak $26.28 \%$, karbohidrat $17.32 \%$, kadar air $9.72 \%$ dan kadar Abu 12.98\%. Pada grade 2 protein $32.84 \%$, lemak $25.03 \%$, karbohidrat $18.77 \%$, kadar air $9.40 \%$ dan kadar Abu $13.96 \%$ dan Pada grade 3 protein $31.61 \%$, lemak $24.63 \%$, karbohidrat $20.59 \%$, kadar air $9.71 \%$ dan kadar Abu $13.46 \%$. Kesimpulan yang diperoleh yaitu 1.) Tepung pakan malla merupakan bahan baku yang berasal dari campuran antara protein hewani (maggot) dan protein nabati (azolla), 2.) Produk tepung pakan malla merupakan suplemen protein pakan ternak dan dapat pula digunakan sebagai bahan baku pembuatan pakan ternak. 3.) Produk tepung pakan malla memiliki turunan produk menjadi tiga grade yang memiliki kandungan protein diatas $30 \%$, dan 4.) Tepung pakan Malla memiliki potensi dalam menunjang pertanian terpadu yang berkelanjutan.
\end{abstract}

Kata kunci: Pakan, Maggot, Azolla, Tepung pakan Malla, Protein

\begin{abstract}
ABTRACT
Availability of feed is a major factor in the success of livestock businesses, both in the form of poultry farms, ruminants, and fish. Feed can be divided into natural food and artificial feed. The main raw material supporting protein that is often used is fish waste, but its availability is fluctuating. Potential alternative raw materials with high protein content include maggot from Hetermia illucens fly which contains animal protein and azolla plants which have vegetable protein content. This writing uses a descriptive method, namely writing that refers to the actual problem solving, data collection, compiled, explained and analyzed. Discussion of problems using literature studies and laboratory test results as a source of information. The result of this activity is the creation of malla feed flour products which have three derivative products made into three grades. The proximate content of Malla grade 1 feed flour includes protein $33.70 \%$, fat $26.28 \%$, carbohydrate $17.32 \%$, moisture content $9.72 \%$ and ash content $12.98 \%$. At grade 2 protein $32.84 \%$, fat $25.03 \%$, carbohydrate $18.77 \%$, water content $9.40 \%$ and ash content $13.96 \%$ and at grade 3 protein $31.61 \%$, fat $24.63 \%$, carbohydrate $20.59 \%$, moisture content $9.71 \%$ and ash content $13.46 \%$. The conclusions obtained are 1.) Malla flour is a raw material derived from a mixture of animal protein (maggot) and vegetable protein (azolla), 2.) Feed flour product malla is a animal feed protein supplement and can also be used as raw material for making animal feed. 3.) Malla feed flour products have a product derivative into three grades that have a protein content above $30 \%$, and 4.) Malla feed flour has the potential to support sustainable integrated farming.
\end{abstract}

Key words: Feed, Maggot, Azolla, Malla Flour, Protein

\section{PENDAHULUAN}

Ketersediaan pakan merupakan faktor utama dari suksesnya usaha peternakan, baik berupa peternakan ungas, pemamah biak, maupun ikan. Penyebab untung ruginya perternak yang terbesar adalah dari kualitas pakan yang diberikan. Pakan dapat dibeda- kan menjadi pakan alami dan pakan buatan. Pakan alami adalah makanan yang keberadaan nya tersedia di alam sedangkan Pakan buatan merupakan campuran dari bahanbahan pakan yang memiliki kandungan nutrisi dan harga yang berbeda-beda (Wardhani dkk, 2011). 
Merk dagang dari pakan buatan yang ada di pasaran saat ini semakin banyak, walaupun harga pakan semakin tinggi. Harga dari pakannya pun bervariasi tergantung dari kandungan protein yang ditawarkan. Kondisi tersebut dikarenakan para peternak belum mampu menyediakan pakan sendiri dengan komposisi yang tepat sehingga dapat menguntungkan. Peternak banyak yang telah mencoba membuat pakan sendiri, namun terkendala dengan ketersediaan bahan baku penunjang protein dan komposisi yang kurang tepat sehingga dapat merugikan petani itu sendiri.

Bahan baku utama penunjang protein yang sering digunakan adalah limbah ikan, namun ketersediaannya fluktuatif. Ketersediaannya tergantung hasil dari nelayan, apabila cuaca baik maka bahan baku cukup banyak dan harga dapat murah namun apabila cuaca buruk ketersediaannya berkurang dan mengakibatkan harga mahal. Hal lain yang mempengaruhi ketersediaan bahan baku dari limbah ikan yaitu produsen pakan besar yang dapat memonopoli bahan baku dan penggunaan lain selain untuk bahan pakan buatan.

Kondisi tersebut apabila terus menerus berlangsung maka yang merugi adalah peternak yang langsung memanfaatkan pakan buatan pabrikan. Perlu adanya solusi untuk mengatasi masalah tersebut. Penggunaan bahan baku alternatif yang dapat tersedia secara berkelanjutan, murah dan berkualitas. Potensi bahan baku alternatif yang memiliki kandungan protein tinggi diantaranya adalah maggot dari lalat Hetermia illucens yang memiliki kandungan protein hewani dan tanaman azolla yang memiliki kandungan protein nabati.

Tulisan ini bertujuan untuk memberikan informasi tambahan tentang potensi bahan alternatif yang dapat digunakan sebagai pengganti tepung ikan yang memiliki kandungan protein tinggi sehingga diharapkan mampu membantu peternak menyediakan pakan yang murah dan berkelanjutan.

\section{METODE}

Penulisan ini menggunakan metode diskriptif yaitu penulisan yang mengacu pada pemecahan masalah yang aktual, pengumpulan data, disusun, dijelaskan dan di analisis. Pembahasan masalah dengan menggunakan studi pustaka dan hasil uji laboratorium sebagai sumber informasi.

\section{HASIL DAN PEMBAHASAN}

Tepung pakan Malla merupakan produk suplemen pakan ternak yang memiliki kandungan protein hewani dan protein nabati. Kandungan protein nabati berasal dari tanaman azolla microphila dan protein hewani berasal dari maggot/ larva lalat tentara hitam (Hetermia illucens). Tepung pakan malla ini di bagi menjadi tiga jenis produk yang masing masing memiliki kandungan protein yang berbeda - beda yaitu 31,61 \% - 33,70.

\section{Proses pembuatan tepung pakan "Malla"} Penyediaan Maggot BSF (black soldier fly)

Ketersediaan maggot dari lalat BSF di alam termasuk sedikit dibandingkan lalat rumah (Musca domestica) dan keberadaannya tidak menggerombol seperti halnya jenis lalat yang lainnya sehingga jarang terlihat oleh manusia. Bentuk lalat ini lebih menyerupai lebah dan hidupnya sebagai lalat dalam waktu yang pendek dan lebih panjang pada fase larva atau sering disebut sebagai maggot.

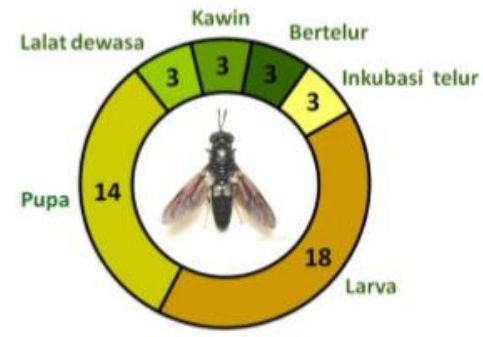

Gambar 1. Siklus hidup lalat BSF (Tomberlin dan Sheppard, 2002) dalam Wardhana, 2016.

Dalam penyediaan maggot perlu mengetahui siklus hidup serangga ini. Beberapa fase yang dilalui selama hidupnya seperti halnya jenis lalat yang lainnya yaitu telur, maggot (larva), prepupa, pupa dan serangga dewasa (Rachmawati, dkk. 2015). Menurut Tomberlin dan Sheppard (2002) dalam Wardhana (2016), fase telur hingga menetas selama 3 hari, fase larva selama 18 hari, fase pupa selama 14 hari, fase lalat selama 9 hari. 
Total siklus serangga ini dari telur hingga dewasa yaitu selama 44 hari (gambar.1).

Black Soldier Fly berwarna hitam dan bagian segmen basal abdomennya berwarna transparan (wasp waist) sehingga sekilas menyerupai abdomen lebah. Hal ini yang dapat menyebabkan masyarakat beranggapan lalat BSF termasuk jenis lebah/tawon. Menurut Wardhana (2016), lalat dewasa tidak memiliki bagian mulut yang fungsional, karena lalat dewasa hanya beraktivitas untuk kawin dan bereproduksi sepanjang hidupnya. Kebutuhan nutrien lalat dewasa tergantung pada kandungan lemak yang disimpan saat masa pupa. Ketika simpanan lemak pada tubuhnya habis, maka lalat akan mati (Makkar et al. 2014).

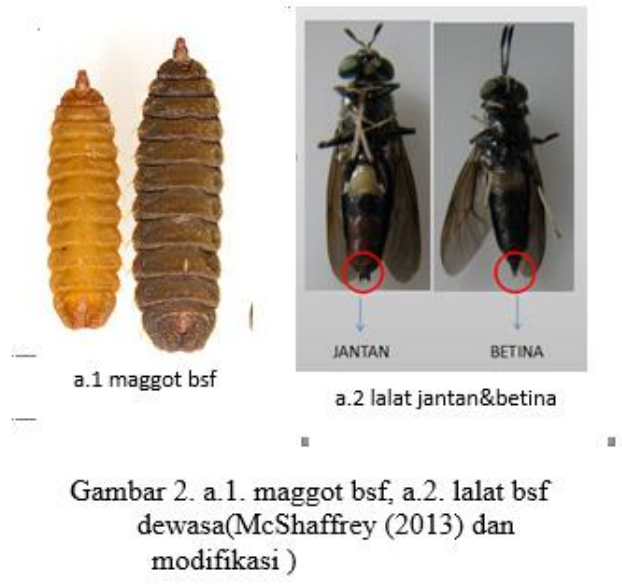

\section{Penyediaan tanaman Azolla}

Tanaman azolla merupakan tanaman jenis paku-pakuan yang hidupnya mengambang di atas permukaan air. Berukuran kecil, lunak, bercabang-cabang tidak beraturan. Azolla berkembangbiak dengan dua cara, yaitu secara generatif (fragmentasi) dan vegetatif. Perbanyakan vegetative terjadi dengan cara pemisahan cabang samping dari cabang utama, yang kemudian membentuk tumbuhan baru (Djojosuwito, 2000).

Biomassa azolla microphylla mengandung protein $24-30 \%$ dari berat keringnya (Lumkin dan Plucknet, 1982) dan berbagai mineral esensial seperti total $\mathrm{N}$ basah tiris 2,80-3,04\% (kering 5-6\%) P2O5 2,02-2,10\%, K2O 9,06- 9.72\%, Ca total 5,88-
6,20\%, Mg total 0,06-0,09\% dan C-organik 40,75-42,88\% (Supartoto, dkk. 2012). Dengan kandungan tersebut tanaman azolla memiliki potensi yang besar dalam membantu memberi nutrisi hewan ternak.

Tanaman ini dapat dibudidayakan dengan membuat kolam yang kedalaman airnya dapat mencapai $10 \mathrm{~cm}$. menurut Hanafiah (2009) dalam Utama (2015), ketinggian air genangan dapat mempengaruhi serapan nitrogen. Sebelum benih tanaman di tebar, pemberian pupuk kandang perlu dilakukan untuk menyediakan nutrisi bagi tanaman azolla. Pembudidayaan tanaman azolla pada kolam membantu mempermudah penyediaan tanaman azolla sebagai bahan baku pakan ternak. Selain pembudidayaan dalam kolam terpal, cara lain yang dapat dilakukan yaitu dengan memanfaatkan kolam tanah dan juga dapat ditumpangsarikan dengan tanaman padi.

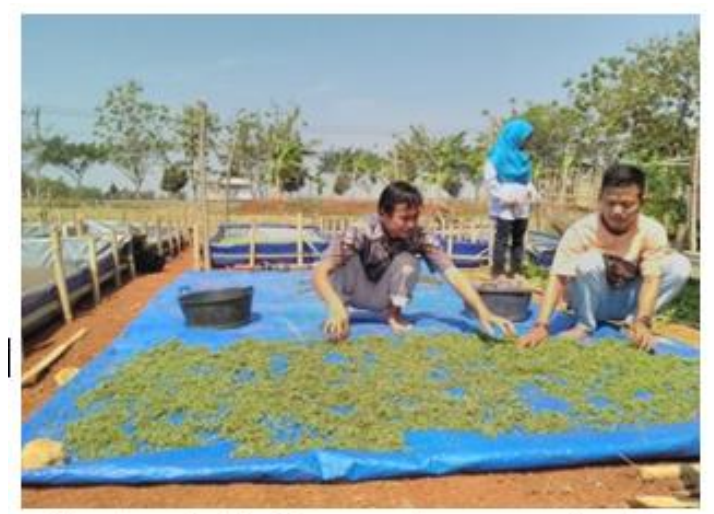

Gambar 3. Penjemuran tanaman Azolla (Dokumen Pribadi)

Pemanenan tanaman dapat dilakukan pada umur mulai dari 3 minggu sampai 4 minggu atau pada saat akar tanaman terlihat gelap yang menandakan tanaman tersebut telah dewasa. Perbedaan umur panen dapat mempengaruhi kandungan nutrisi yang ada pada tanaman azolla. Setelah pemanenan, tanaman azolla dapat dikeringkan dengan cara menjemur dibawah sinar matahari langsung (gambar 3.).

\section{Metode Pembuatan Tepung "MALLA"}

Proses pembuatan tepung pakan malla sesuai dengan gambar 2. yang terdiri dari:

1. Penyediaan bahan Maggot/larva lalat Hetermia illucens. 
- Budidaya indukan lalat tentara (Hetermia illucens)

- Pengambilan telur lalat tentara

- Penetasan telur pada tempat khusus ( \pm umur 2-5 hari)

- Pembesaran maggot sebagian untuk pembuatan tepung ( \pm umur 27-30 hari) dan sebagian lagi untuk indukan (didiamkan hingga menetas)

- Pemanenan Maggot yang akan digunakan sebagai tepung pada umur 27-30 hari

- Pengovenan/pengeringan

- Penggilingan hingga menjadi tepung

2. Penyediaan bahan Azolla microphyla.

- Budidaya tanaman Azolla microphilla

- Pemanenan tanaman Azolla saat akar berwarna hitam ( \pm umur 7-10 hari)

- Penjemuran/ Pengeringan tanaman

- Penggilingan tanaman Azolla yang telah kering hingga menjadi tepung

3. Pencampuran tepung maggot dan tepung azolla sesuai dengan grade kandungan protein yang diharapkan dengan komposisi perbandingan sebagai berikut:
a. Grade $1=1: 1 \quad$ (Maggot : Azolla)
b. Grade $2=1: 1.5$ (Maggot : Azolla)
c. Grade $3=1: 2$ (Maggot: Azolla)

4. Proses pengemasan menggulakan plastik transparan berlabel dengan menggunakan alat sealer/pengepres

5. Produk jadi tepung pakan dengan nama produk "MALLA" dari singkatan Maggot dan Azolla.

\section{Hasil Analisis Tepung Pakan}

Hasil analisis dari produk tepung pakan Malla di peroleh kandungan proksimat yang terdiri dari kandungan protein, lemak, karbohidrat, kadar air dan abu sesuai dengan tabel 1 .

Tabel 1. Kandungan proksimat tepung pakan

\begin{tabular}{|c|l|l|l|l|l|l|}
\hline $\begin{array}{c}\text { N } \\
\text { o. }\end{array}$ & $\begin{array}{c}\text { Kandungan } \\
\text { Proksimat }\end{array}$ & Maggot & Azolla & $\begin{array}{c}\text { Grade } \\
\mathbf{1}\end{array}$ & $\begin{array}{c}\text { Grade } \\
\mathbf{2}\end{array}$ & $\begin{array}{c}\text { Grade } \\
\mathbf{3}\end{array}$ \\
\hline 1. & Protein (\%) & 45.84 & 13.23 & 33.70 & 32.84 & 31.61 \\
\hline 2. & Lemak (\%) & 27.91 & 16.65 & 26.28 & 25.03 & 24.63 \\
\hline 3. & Karbohidrat (\%) & 5.16 & 46.33 & 17.32 & 18.77 & 20.59 \\
\hline 4. & Kadar Air (\%) & 5.80 & 12.55 & 9.72 & 9.40 & 9.71 \\
\hline 5. & Kadar Abu (\%) & 15.29 & 11.24 & 12.98 & 13.96 & 13.46 \\
\hline
\end{tabular}

Malla.

Keterangan: Uji dilakukan di Laboratorium Tanah/ Sumberdaya Lahan Fakultas Pertanian, Universitas Jenderal Soedirman, grade $1=1: 1$ (maggot : azolla), grade $2=1: 1.5$ (maggot $:$ azolla), grade $3=1: 2$ (maggot : azolla)

Kandungan Protein yang dihasilkan dari uji laboratorium dengan menggunakan metode Kjeldahl. Hasil yang diperoleh pada maggot sebesar $45.84 \%$, pada azolla sebesar $13.23 \%$. Setelah dilakukan percampuran hasil tertinggi yaitu pada grade 1 yaitu sebesar $33.70 \%$ dan diikuti pada grade 2 dan grade 3 sebesar $32.84 \%$ dan $31.61 \%$. hasil yang diperoleh sesuai dengan komposisi pencampuran antara tepung maggot dan azolla yang semakin banyak kandungan tepung maggot semakin tinggi protein yang di peroleh.

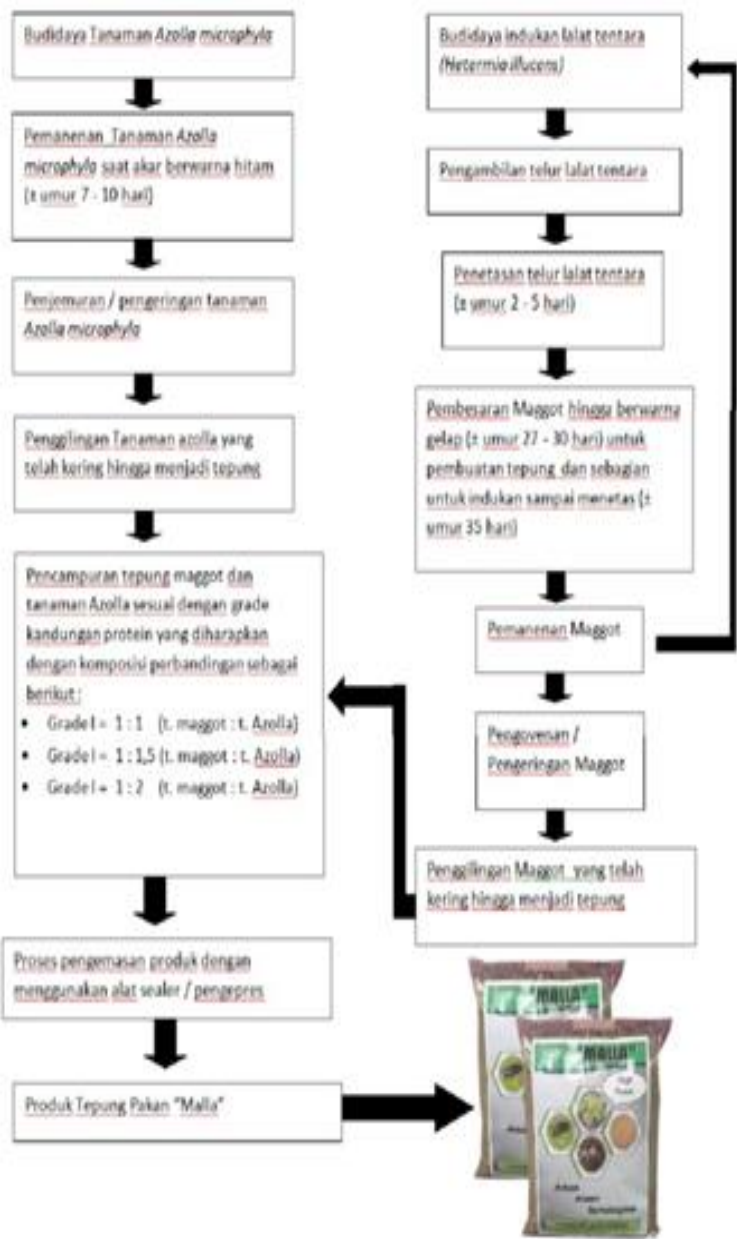

Gambar 4. Diagram proses pembuatan produk tepung pakan "malla".

Kandungan lemak yang diperoleh dengan uji menggunakan metode soxhlet dengan hasil yaitu pada maggot diperoleh sebesar $27.91 \%$ dan pada azolla diperoleh sebesar 16.65\%. Setelah dilakukan percampuran hasil tertinggi kadungan lemaknya pada grade 1 yaitu sebesar $26.28 \%$ dan diikuti pada grade 2 dan grade 3 sebesar 
$25.03 \%$ dan $24.63 \%$. Nilai tertinggi sampai terendah kandungan lemak sama dengan kandungan protein yaitu grade 1 ,grade 2 dan grade 3 .

Kandungan karbohidrat yang yang diperoleh dengan uji menggunakan metode Kalkulasi dengan hasil yaitu pada maggot diperoleh sebesar $5.16 \%$ dan pada azolla diperoleh sebesar $46.33 \%$. Setelah dilakukan percampuran hasil tertinggi yaitu pada grade 3 yaitu sebesar $20.59 \%$ dan diikuti pada grade 2 dan grade 1 sebesar $18.77 \%$ dan $17.32 \%$. Hasil ini berbanding terbalik dengan hasil yang diperoleh dari kandungan protein dan lemak. Hal ini disebabkan oleh kandungan karbohidrat yang tertinggi dimiliki oleh tepung azolla sehingga setelah dicampurkan, kandungan tertinggi pada perbandingan tepung azolla terbanyak sedangkan pada tepung maggot yang tinggi kandungan karbohidratnya rendah.

Kadar air dan kadar abu di uji menggunakan metode gravimetri. Kandungan kadar air dari bahan tepung maggot diperoleh sebesar $5.80 \%$ sedangkan pada tepung azolla sebesar $12.55 \%$. Hasil uji pada ketiga grade bahan malla diperoleh hasil dibawah $10 \%$ yaitu sebesar $9.72,9.42$ dan 9.71 pada grade 1, 2 dan 3. Hasil uji kadar abu pada tepung maggot sebesar $15.29 \%$ dan pada tepung azolla sebesar $11.24 \%$. Kadar abu pada tepung malla diperoleh pada grade 1 sebesar $12.98 \%$, pada grade 2 sebesar $13.96 \%$ dan pada grade 3 sebesar $13.46 \%$.

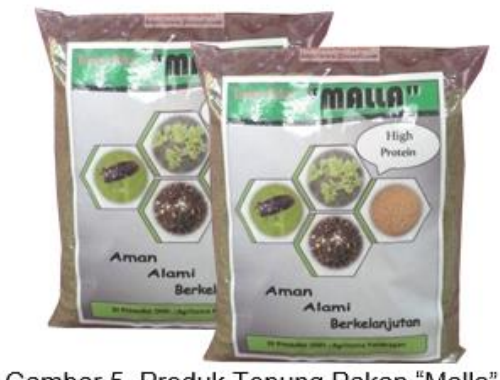

Gambar 5. Produk Tepung Pakan "Malla"

\section{Spesifikasi Produk}

Produk ini dibuat melalui Program Calon Perusahaan Pemula Berbasis Teknologi Dari Perguruan Tinggi (CPPBT), Kementerian riset, teknologi, dan pendidikan tinggi tahun 2017 dengan judul "Tepung Pakan "Malla" Sebagai Protein Alternatif Pakan Ternak" dengan spesifikasi produk sebagai berikut :
- Kandungan Protein lebih dari $30 \%$

- Bahan berbentuk tepung

- Berat bersih 800 gram per kemasan

- Terbuat dari campuran maggot Hetermia illucens dan tanaman Azolla microphyla

- Dapat digunakan sebagai campuran ternak unggas, ruminansia dan ikan.

\section{Keunggulan Produk}

Produk ini memiliki beberapa keunggulan yaitu:

- Tepung Pakan MALLA merupakan produk alami yang aman bagi binatang ternak karena terbuat dari campuran maggot lalat Hermetia illucens dan tanaman Azolla sp. yang bebas virus dan memiliki kandungan protein tinggi dan serat.

- Dapat digunakan sebagai bahan dasar pembuatan pakan pelet dalam memenuhi kebutuhan protein tinggi pengganti tepung ikan.

- Bentuk yang praktis berupa tepung sehingga mudah diaplikasikan dan penyimpanannya awet dalam jangka waktu yang lama.

\section{KESIMPULAN}

1. Tepung pakan malla merupakan bahan baku yang berasal dari campuran antara protein hewani (maggot) dan protein nabati (azolla).

2. Produk tepung pakan malla merupakan suplemen protein pakan ternak dan dapat pula digunakan sebagai bahan baku pembuatan pakan ternak.

3. Produk tepung pakan malla memiliki turunan produk menjadi tiga grade yang memiliki kandungan protein diatas $30 \%$.

4. Tepung pakan Malla memiliki potensi dalam menunjang pertanian terpadu yang berkelanjutan.

\section{DAFTAR PUSTAKA}

Djojosuwito, S. 2000. Azolla "Pertanian Organik dan Multiguna.Penerbit Kansius. Yogyakarta.

Makkar HPS, Tran G, Heuze V, Ankreas P. 2014. State of the art on use of insects as animal feed. Anim Feed Sci Technol. 197:1-33. 
McShaffrey D. 2013. Hermetia illucens-Black Soldier Fly Hermetia illucens. Bugguide.net (on line). Diakses pada tanggal 31 mei 2017 dari: http: bugguide.net/node/view/874940/ bimage.

Suciati, R. dan H. Faruq, 2017, Efektifitas Media Pertumbuhan Maggots Hermetia Illucens (Lalat Tentara Hitam) Sebagai Solusi Pemanfaatan Sampah Organik , J. Biosver 2(1): 8-13.

Supartoto, P. Widyasunu, Rusdiyanto dan M. Santoso. 2012. Eksplorasi Potensi Azolla microphylla dan Lemna polyrhizza Sebagai Produsen Biomassa Bahan Pupuk Hijau, Pakan Itik dan Ikan. Prosiding Seminar Nasional"Pengembangan Sumber Daya Pedesaan dan Kearifan Lokal Berkelanjutan II", purwokerto 27-28 November 2012. P: 217-225.

Utama, P., D. Firnia dan G. Natanael, 2015.Pertumbuhan Dan Serapan Nitrogen Azolla microphylla Akibat Pemberian Fosfat dan Ketinggian air yang berbeda. J.Agrogolia 4(1):41-52.

Wardhana, A.H. 2016. Black Soldier Fly (Hermetia illucens) sebagai Sumber Protein Alternatif untuk Pakan Ternak. J. Wartazoa 26(2): 69-78.

Wardhani, L.K., M. Safrizal dan A.Chairi, 2011, Optimasi Komposisi Bahan Pakan Ikan Air Tawar Menggunakan Metode Multi-Objective Genetic Algorithm, Seminar Nasional Aplikasi Teknologi Informasi.Yogyakarta 17-18 juni 2011, P: 112 - 117 (On line) Di akses dari https://journal.uii.ac.id/Snati/article/view 12182/2008. 